European journal of American studies

Special Issue: Women in the USA

\title{
Dangerous Liaisons: Working Women and Sexual Justice in the American Civil War
}

E. Susan Barber and Charles F. Ritter

\section{Q OpenEdition}

\section{Journals}

Electronic version

URL: https://journals.openedition.org/ejas/10695

DOI: 10.4000/ejas.10695

ISSN: 1991-9336

Publisher

European Association for American Studies

Electronic reference

E. Susan Barber and Charles F. Ritter, "Dangerous Liaisons: Working Women and Sexual Justice in the American Civil War", European journal of American studies [Online], 10-1 | 2015, document 2.3, Online since 31 March 2015, connection on 08 July 2021. URL: http://journals.openedition.org/ejas/10695; DOI: https://doi.org/10.4000/ejas.10695

This text was automatically generated on 8 July 2021.

Creative Commons License 


\title{
Dangerous Liaisons: Working Women and Sexual Justice in the American Civil War
}

\author{
E. Susan Barber and Charles F. Ritter
}

1 Mary Kirksey was a thirty-three-year-old white widow living in Lookout Valley, Tennessee, when the Union Army moved into her area in November 1863 following the Battle of Chattanooga. ${ }^{1}$ By May of 1864, Kirksey was accustomed to the presence of Union troops in and around her home. During the previous six months, her house and an adjoining stable had served as the headquarters for the $28^{\text {th }}$ Pennsylvania Regiment, and as a temporary hospital for two Union soldiers recovering from amputations. To support herself and her fourteen-year-old son, John, Mary did sewing and laundry for Union troops and sold them milk and eggs. The frequent visits by Union soldiers to Kirksey's home may have led Charles Hunter, a private in the $7^{\text {th }}$ Kentucky Cavalry, to believe that Kirksey was offering something more than clean and mended clothes. On May 18, he brutally raped Kirksey in her home after tying her arms with her apron strings and binding her mouth with a leather strap. A day after the assault Hunter returned and raped Kirksey again. ${ }^{2}$

2 Grace Barnes, a young, free woman of color, might have understood what Mary Kirksey experienced. Barnes did washing for Union troops stationed at Pongo Bridge Camp about ten miles south of Norfolk, Virginia. On the morning 
of April 28, 1864, as Barnes made her way home with a load of dirty laundry, seven soldiers from the $20^{\text {th }}$ New York Cavalry dragged her into the bushes where six of the men took turns raping her. One man also tortured her sexually by penetrating her with pins and sticks. The assault left Barnes in a state of physical and emotional collapse and probably suffering from a damaged bladder. ${ }^{3}$ And a few weeks before Kirksey and Barnes were attacked, Lucy Parker, a white matron in a military hospital in Chicago, Illinois, was assaulted by J.C. Webb, a hospital steward, who attempted to drag her into a bedroom on the afternoon of March 8, 1864. J.A. Jackson, the hospital surgeon who treated Parker for two weeks following the attack, reported that she was "bruised in the left groin and on the thigh" and was "suffering from intense pain with profuse flowing" from the womb. Parker did not proffer charges but a complaint that Jackson filed on her behalf yielded a guilty verdict for Webb who was dismissed from the service. ${ }^{4}$

3 Grace Barnes, Lucy Parker, and Mary Kirksey are a few of the thousands of white and black American women who were drawn into paid and unpaid work for the Union and Confederate armies during the American Civil War. Based on pension records located in the National Archives in Washington, D.C., one scholar has estimated that at least twenty thousand women worked in Union and Confederate military hospitals between 1861 and 1865. ${ }^{5}$ As Union armies marched south, thousands more women cooked food and laundered clothing for the soldiers. Some women-like the black laundresses attached to the $4^{\text {th }}$ Corps d'Afrique-were part of adjunct units that accompanied Union troops. Others, like Mary Kirksey, were destitute Southern women in Union-occupied areas whose domestic services provided money to keep their families from starvation. Some were newly-freed slaves like Jennie Green who lived in the contraband camp at Fortress Monroe near City Point, Virginia, and was raped in April of 1864 when she was ordered to the officers' quarters to prepare a meal for a young lieutenant. ${ }^{6}$ The Union army, therefore, provided some women with a reliable source of wartime income. At times, however, the army's proximity also represented a dangerous liaison that drew working women into closer contact with Union troops and, thus, rendered them increasingly vulnerable to sexual assault. 
4 Wartime rape is certainly not an unusual occurrence as the experiences of Japanese comfort women in World War II and women in Rwanda, Bosnia-Herzegovina, the Sudan, and other locations have made manifest. Yet, until recently, the wartime rape of white and black women in the American Civil War has been shrouded in mystery, leading many Civil War scholars to conclude that the conflict was a "no-rape" or "low-rape" war and that any assaults that might have occurred were few and based solely on anecdotal evidence. ${ }^{7}$ Recent research, however, using courts-martial cases in the Judge Advocate General's records for the Union Army, has revealed that Kirksey, Barnes, and Parker were not three isolated cases. During the American Civil War, over four hundred white and black women and girls ranging in age from 5 to 82 brought charges of rape, attempted rape, and other crimes of sexual intimidation against Union soldiers and civilians contracted to perform services for the Union army.

${ }_{5}$ Researching sexual crimes poses complex challenges. The acts these trials describe are frequently violent and contain sometimes horrific images that are difficult to contemplate much less examine in detail. There is a natural proclivity to cloak such aberrations in silence or refer to them obliquely by euphemistic phrases. Even today, women are reluctant to bring sexual assault charges forward out of fear that they won't be believed or that the justice they seek might prove elusive. Thus, the number of sexual assaults that can be documented through surviving records represents a fraction of those that actually occurred. Studies of rape in contemporary American society reveal that, between 1992 and 2000, only 63 per cent of completed rapes and 65 per cent of attempted rapes were reported to the police. ${ }^{8}$ This must have been even more the case in mid-nineteenth-century America when white women's purity was a highly prized commodity and a woman's disclosure of such a crime risked her own character being exposed to a high level of scrutiny for evidence that she was somehow complicit in the attack. Added to this is the fact that these assaults took place in the context of war when women's bodies often became a terrain on which the war was waged. ${ }^{9}$ Tried by military tribunals where the judges and officers of the court were clad in the uniform of the enemy (when conducted in the South), these sexual assault trials are multi-voiced, sometimes conflicting narratives that describe the event not 
only from the point of the victim and the assailant but also from that of a host of witnesses for either side, including commanding officers, fellow soldiers, medical professionals, clergy, neighbors, and family members. ${ }^{10}$ What makes these 420 cases most significant, however, is the Union Army's response. When women, or their kin, came forward to military authorities to accuse soldiers of sexual misbehavior, they apparently did so with a presumption that their charges would be heard. This is especially noteworthy for black women for whom sexual justice in the south was virtually unknown. In the U. S. army's courts-martial, however, they at least received a hearing if not always sexual justice.

6 The army's court-martial system, its arbiter of military justice, was not designed to deal with issues of sexual justice. It adjudicated infractions of the Articles of War which did not include sexual misconduct such as rape and attempted rape. Yet, as Union ranks swelled, the numbers of these civilian crimes grew also. Hence, when the American Civil War began in April of 1861 rape was not a military crime. The U.S. Congress militarized it-when committed by military personnel-in March of 1863, along with a number of other civilian crimes including arson, robbery, and murder. ${ }^{11}$ By the time this bill was passed, however, more than thirty Union soldiers-including some officers-had been brought before courts-martial for varying crimes of sexual misconduct; twenty-four were found guilty and two had been executed. ${ }^{12}$ In the absence of a definition of rape in federal law, military courts relied on the British common law definition of rape as "carnal knowledge of a woman forcibly and against her will," a definition that had been adopted by many U.S. states. ${ }^{13}$ Attempted rape or sexual assault covered a broader range of sexual misconduct which included unwelcome kissing, fondling, and lewd suggestions. Procedurally, Union judge advocates, the men who prosecuted cases before the courts-martial, were instructed to follow the law in the state where the crime took place. Since most of the crimes occurred in Southern territory, this meant that black women could be prohibited from bringing sexual assault charges against a white assailant and barred from testifying against him in court, since this was the law in all Southern states. However, U. S. courts-martial panels never prevented blacks from testifying against whites or blacks on the basis of race, thus giving black women, for the first 
time, a legal voice with which to accuse white men of sexual violation. This was an extremely progressive policy to establish, and it was sanctioned at the highest levels of the United States government.

7 Military laundresses, most of whom were black women, traveled with the army and lived in separate quarters in the camps which made them especially vulnerable to sexual assault. This was the case at Fort Jackson, Louisiana, where shortly after taps on January 25, 1864, Keziah and Laura Davis, Emma Smith, Elizabeth Dallas, Rose Plummer, and Elizabeth Taylor were terrorized by four white officers from the $4^{\text {th }}$ Regiment Corps d'Afrique. Under cover of their authority as Officer of the Day and Officer of the Guard, Captains William Knapp and Charles Goff, accompanied by two lieutenants, forced their way into the laundress's cabins, exposing themselves, making lewd suggestions, and insisting that they be allowed to spend the night. Captain Knapp offered Keziah Davis a bucket of oysters for the privilege but she refused and scorched him with a candle after he pushed her against the wall. According to her testimony, Knapp later implored her not to reveal the escapade.

8 After being repulsed by Davis, the four men made their way into the other laundresses' cabins. At Elizabeth Taylor's cabin, Captain Goff and Lieutenants William O'Dell and Harold Blakeslee broke open the door and pinned her on the bed. Goff attempted to get in bed with her but Taylorwho was married to a soldier in the $4^{\text {th }}$ Corps d'Afriqueresisted. When Goff called her a bitch, Taylor replied that she "was no more a bitch than he was a son-of-a-bitch." Lieutenant O'Dell taunted Goff, saying "if he was Officer of the Day, he wouldn't take that." Goff reacted by striking Taylor three times with his sword. When James Idell, a black soldier on duty at the boathouse, came to the women's defense, remarking that "it was a sin and a shame" the way the laundresses were being abused, Goff arrested him and sent him to the guardhouse. After being found guilty of their crimes, these four white officers were dismissed from the service for what their commanding officer referred to as behavior that was "utterly disgraceful and indecent." ${ }^{14}$

9 No less vulnerable to abuse were laundresses who worked in army hospitals. Jane Leary and Kate Aston, white laundresses who worked at the Convalescent Hospital in St. 
Augustine, Florida, were saved from an imminent sexual assault by Laurence Dorgan and Alonzo Nightingale when Surgeon Adolph Mayer broke into the room and ordered the men to leave. ${ }^{15}$ Rebecca Ann Cradle was not so lucky. She spent several days in the contraband hospital in New Bern, North Carolina, in what assistant surgeon H. G. Meminger termed "a state of wild mania" following her assault by hospital steward Eugene Hannel. At a court of inquiry investigating Cradle's assault, she testified that Hannel asked her to fetch a pitcher of water and bring it to his quarters. When Cradle returned Hannel locked and bolted the door and asked her "to be his girl"-a euphemism that Cradle knew meant that Hannel wanted her to be his personal servant and mistress. When she refused, Hannel became threatening, telling her that "he was the head man in the hospital and that all the girls belonged to him." Cradle's reply that "her body was hers and not his" was a bold statement for a black woman in the South because it laid claim to her own personal and sexual identity. Her words so enraged Hannel that he struck her on the head with his fist, threw her on the bed, and continued with the assault, during which Cradle passed out. Conflicting testimony from two witnesses makes it unclear whether Cradle's mania was induced by the sexual assault itself or by her ingestion of cantharides, or Spanish fly, which Hannel may have administered to her. Evidence of the rape was much clearer. Three doctors who examined Cradle in the hospital concurred that her hymen had recently been ruptured and that her genitalia bore the marks of a violent assault. ${ }^{16}$

${ }_{10}$ Hannel's attorney, E. W. Carpenter, used his closing argument to lecture the panel on North Carolina law concerning the rape of black women and sexual relations between the races. He opined that

In Southern estimation, generally, as well as by the laws of North Carolina, a Negress is deemed incapable of an injury of this kind; not allowing any punishment for violating the chastity of her, who, from a general instinct, habit, and a course of promiscuous indulgence, from motives both of lucre and pleasure, is presumed not to have any chastity, or at least no regard for it.

After a Negress has frequently enjoyed the amorous embrace of a white man, she among the Black Diamonds is considered a superior personage, and entitled to the honors of an aristocrat; they resort to stratagem to seduce and seek every opportunity possible to fulfill the measure of their so-called aristocrtic ambition. 
12 construe Cradle's assailant as the injured party. They recommended that Hannel be sentenced to two years at hard labor at Fort Macon, North Carolina. Brigadier General Palmer, the commanding officer of the occupying forces at New Bern, North Carolina, was equally unimpressed. He called Carpenter's words about Cradle's sexuality "simply inhuman." Palmer, however, doubted that conflicting testimony in the trial could sustain the rape charge and reduced Hannel's sentence to three months in the New Bern jail and dishonorable discharge from the army, a fate that the court had not visited on him. ${ }^{17}$

${ }_{13}$ Hannel's case was reviewed in Washington where Judge Advocate General Joseph Holt stated that "the testimony of the woman who was ravished fully justified the sentence pronounced by the court [i.e., two years in prison]. The punishment as mitigated by Genl. Palmer is believed to fall far short of what the prisoner richly deserves to suffer." ${ }^{18}$

${ }_{14}$ Women who cooked and baked for the troops or who sold clothing and other supplies in the camps were also targets of sexual abuse by Union soldiers. On April 12, 1864, twenty-two-year-old Sarah Jane Sedman, for example, was raped at knifepoint by Thomas Bond-a private in the $9^{\text {th }}$ Pennsylvania Reserve Corps-about a half-mile from the army's encampment at Manassas, Virginia, as she walked home from camp after selling socks she knitted for Union soldiers. Bond was convicted and sentenced to be dismissed from the service and imprisoned for fifteen years. His conviction was overturned by Major General George Meade on a trial irregularity. ${ }^{19}$ And on June 8, 1864, Lucy Batkins was accosted by Robert Hughes, a black teamster under contract to the Quartermaster's Corps, who stopped at her home in New Kent County, Virginia, for something to eat. She escaped assault when her fifty-year-old mother and Eliza, a female servant, foiled the attack. Hughes was found guilty of assault and battery with intent to rape and sentenced to be hanged-an extremely harsh sentence for an attempted rape. His sentence was approved by Major General George Meade and President Lincoln. ${ }^{20}$

${ }_{15}$ Quick thinking also saved the daughters of W. H. Hall, a white widowed sutler ${ }^{21}$ who sold baked goods and beer from a small store on the grounds of Ft. Nelson, Kentucky, twenty miles south of Nashville. Near midnight on January 
7, 1865, two captains-Samuel Fitch and Jacob Schuckpounded on the door of the Hall cabin, demanding to be admitted. When seventeen-year-old Martha opened the door, Fitch barged in, declaring "This is a damned whore house [and] I intend to fuck some of you before I leave." One of Hall's six daughters immediately left the cabin, running barefooted through the snow to alert a neighbor who summoned the company guard. After a brief scuffle with Hall and at least two of his daughters, the two men were taken into custody. Hall pressed charges against the two intruders within a matter of days. ${ }^{22}$

${ }_{16}$ At trial, Jacob Schuck's lawyer raised an all-too-common defense that relied on stereotypical gendered notions of male and female sexuality in times of war-that women in or near military camps were sexually available and that sexual transgressions against women during wartime were understandable if not excusable when committed by otherwise valiant and honorable men who were spilling their blood for their country. "It is not necessary for our purposes," he observed

to prove that the reputation of this house was bad [...]. [T]he fact of their living at Camp Nelson in a drinking house[...]cast a dark shade of suspicion upon ... the character of the house [...]. But," he continued, "is this Court about to punish severely a fellow officer for such an offence, when they must know if not from experience, at least from observation and report, that officers of all ranks and from all countries are guilty of the same offense [...]. If the facts of this Court are such as to justify and demand the severe punishment of the accused, pray tell us what would become of the army, both rank and file? Were the army held strictly accountable, on charges of this nature, we greatly fear there would not be soldiers enough with officers to command them, to conquer Mexico, much less France and England, and the rest of the world. We may have use for our officers. Don't lightly dismiss them from the Service.

17 Unfortunately for the two defendants, the court-martial was not persuaded and both Fitch and Schuck were dismissed from the service. ${ }^{23}$

${ }_{18}$ The accusation that women workers in military encampments were prostitutes was offered in a number of the trials as an explanation for the sexual assault. In defense of the rape charged by Mary Kirksey, for example, Charles Hunter testified that Kirksey had a reputation as a "bad woman" and offered this as a justification for the assault that left Kirksey bruised and sobbing on the floor. Assistant Surgeon Charles Lauer used a similar defense in 1863 to explain his "inspection" of the genitalia of Sarah Allen and Jane Taylor, two black laundresses in Beaufort, South Carolina, to ascertain if they were infected with 
venereal disease. Lauer was charged with numerous crimes against women and young girls while stationed at Port Royal Station, South Carolina. He was found guilty by a court-martial but given a light sentence-a two-month suspension from work and pay. The unknown officer who reviewed Lauer's case upheld the conviction and offered a "public reprimand" of Lauer for his "disgusting record of sexual misbehavior." ${ }^{24}$

${ }_{19}$ Indeed both the Union and Confederate armies shared concerns about the prevalence of prostitutes in areas where the armies were encamped, in part because of reports of prostitutes in the camps, usually to minister to the sexual appetites of commanding officers. John Barger, for example, a captain in the $11^{\text {th }}$ Tennessee Cavalry, kept his mistress, Amanda McGee, in camp.She accompanied him on horseback when the army was on the march. He was eventually found guilty of conduct unbecoming an officer and a gentleman and dismissed from the service. ${ }^{25}$ Captain Jerome B. Taft, a twenty-one-year-old recruiting officer for the $59^{\text {th }}$ New York Infantry, was found guilty of convincing Harriet Merrill to cross-dress as a Union soldier so she could be smuggled into camp where she served as Taft's mistress. He, too, was dismissed from the service. ${ }^{26}$ And Captain Samuel N. Stanford, of the $1^{\text {st }}$ Ohio Cavalry, was, likewise, accused of

$$
\begin{aligned}
& \text { associat[ing] and cohabit[ing] with one Martha Moore, a woman of ill character and } \\
& \text { repute, sleeping at her house in Stevensburg[,] Va., bringing her into his company } \\
& \text { quarters, and otherwise associating with her, to the great Scandal of the Military } \\
& \text { Service of the United States, to the almost total neglect of his Company, and to the } \\
& \text { predudice [sic] of good order and Military discipline. }
\end{aligned}
$$

The court-martial found Stanford guilty in April of 1864 and recommended that he be cashiered from the service. Major General George Meade approved the sentence. ${ }^{27}$

${ }_{21}$ Sometimes judge advocates were able to rebut attempts to cast women as prostitutes. In Jacob Schuck's case, his lawyer's attempt to frame Schuck's behavior in genderspecific terms that aligned the all-male court-martial panel with the sexual escapades of two junior officers with allegedly loose women-women who had somehow sacrificed their respectability by providing domestic services for the U.S. Army-failed miserably. The judge advocate in this case, Colonel John E. Cummings, $185^{\text {th }}$ Ohio, rebutted the attempt by drawing sharp class distinctions between Schuck and Fitch and the young 
female plaintiffs: "there is too much disposition," he observed, "among certain classes of fast young gentlemen in the community to act upon this principle that the poor cannot be virtuous and they are subject to frequent indignities on account of their poverty from young men holding higher stations in life." Schuck and Fitch were found guilty and sentenced them to be dishonorably dismissed. ${ }^{28}$

${ }_{22}$ In other cases, however, the charge that the woman was a sex worker constituted a powerful weapon that could be used to discredit the woman's character and obtain an acquittal. Jennie Green's assault at Fortress Monroe near City Point, Virginia, in May of 1864, illustrates how effective this defense could be in the hands of a skilled defense attorney. On May 17, 1864, Green, an adolescent contraband, was raped by Andrew J. Smith, a white officer in the $11^{\text {th }}$ Pennsylvania Cavalry. At trial, Green testified that Smith, a twenty-six-year-old former lawyer, dragged her into an empty room, threw her on the floor, threatened to kill her, and then "did the same thing that married people do." ${ }_{29}$ Green's testimony was corroborated by William Hunter, the black chaplain of the $4^{\text {th }}$ U.S. Colored Troops, and by Nellie Wyatt, who, like Green, lived in the contraband camp, where the two former slaves cooked and washed for Union troops. Smith was found guilty of rape and conduct unbecoming an officer and a gentleman and was sentenced to dismissal from the service and confinement in a penitentiary for ten years at hard labor. But the court-martial panel that tried Smith's case enclosed a plea for clemency with the trial transcript they forwarded for review. "We the undersigned members of the General Court-martial," they wrote,

\footnotetext{
taking into consideration the previous good character of the accused[,] his family relation (it appearing outside the record that he has a wife and child dependant [sic]upon him for support) and all the circumstances of the case; cannot refrain from the expression of a desire [...] to recommend Lieut. Smith to the mercy of the Reviewing Office, and respectfully suggest the term of imprisonment proscribed by the Code of Virginia, as embodied in our sentence, be commuted in whole or in part.
}

Although officials who reviewed this case, including Major General Benjamin Butler, Judge Advocate General Joseph Holt, and Secretary of War Edwin Stanton opposed clemency, President Lincoln, in an uncharacteristic move, requested that attorney William Johnston review the proceedings. In his report to Lincoln, Johnston redefined 
Jennie Green's identity from witness Nellie Wyatt's description of her as "nothing at all but a child" to "a wicked woman who fails in her attempt to seduce a man, as in the case of Potiphar's wife, ${ }^{30}$ [and] pretends that an attempt was made to ravish her [...]. Courts-Martial," Johnston wrote,

do not sit to try offenses against good morals so much as offenses against our
country. At this moment the highest morality is devotion to our country and the
deepest curse is treason. Had Lieut. Smith by words or actions given aid and
comfort to the enemy, had he lacked zeal or devotion to his duties as an officer and
a soldier [...] I should have rejoiced to see him punished. [But based on] the good
character of the young man; the valuable services he has rendered, and the vague,
contradictory, and unsatisfactory character of the evidence against him; the
recommendation of the officers who tried him ought to be followed.

Smith received a presidential pardon for the unexecuted portion of his sentence which was $9^{1 / 2}$ years. ${ }^{31}$

${ }_{25}$ War is unkind to civilians, especially women who are caught in the crossfire; if injured, they are frequently referred to as collateral damage. ${ }^{32}$ From the evidence of the court-martial cases during the American Civil War, it does not appear that the Union command saw waging a sexual war on women as furthering their military objectives, as the many statements from Union officers and from the Judge Advocate General of the Army attest. Still, women, mainly Southern women, were subject to brutal sexual attacks by Union soldiers. Women who worked in close proximity to Union camps-hospital workers, cooks, laundresses, and other purveyors of goods-were especially vulnerable. Some four hundred of those assaulted sought sexual justice through military tribunals. Forsome of those women sexual justice had never existed in the courts of the antebellum South. Adding to its role as upholder of the Articles of War, the U. S. Army court-martial system, thus, attempted to exert some measure of sexual discipline over its troops and to provide some measure of sexual justice to the women.

${ }_{26}$ The system was never perfect. While military courts broke new ground by permitting black women to bring sexual assault charges against white soldiers, court-martial panels were not colorblind. As the fate of Robert Hughes, the black teamster, suggests they convicted black soldiers at a higher rate than they did white soldiers and they rendered harsher sentences against black men. The Grace Barnes cases further demonstrate that courts-martial were more likely to mitigate sentences for soldiers of either race if the victims were black. In the Barnes cases, seven white 
soldiers were accused of brutally raping the young, black laundress. Six of the men received guilty verdicts and were sentenced to a variety of punishments ranging from discharge from the service to death. However, all but one of these guilty verdicts were overturned on review by the commanding officer and the men were returned to duty. Of the seven, only James Halon-who was tried by a different court-martial than the other six men and who was originally sentenced to death-served any jail time. ${ }^{33}$ In the face of these stark realities perhaps what may matter most regarding sexual crimes in the American Civil War is that the U.S. military courts attempted to achieve some measure of sexual justice to women brutalized in the conflict, an effort that had never before been undertaken.

\section{NOTES}

1. Portions of this article have been previously published. E. Susan Barber and Charles F. Ritter, “'Unlawfully and Against Her Consent': Sexual Violence and the Military during the American Civil War," in Sexual Violence in Conflict Zones: From the Ancient World to the Era of Human Rights, Lisa Heinemann, ed. (Pittsburg: University of Pennsylvania Press, 2011); and E. Susan Barber and Charles F. Ritter, “'Physical Abuse...and Rough Handling': Race, Gender, and Sexual Justice in the Occupied South," in LeeAnn Whites and Alecia P. Long, eds., Occupied Women: Gender, Military Occupation, and the American Civil War (Baton Rouge, LA: LSU Press, 2009).

2. Trial of Charles C. Hunter, $7^{\text {th }}$ Kentucky Cavalry, NN1921, R.G. 153, Records of the Judge Advocate General's Office (U.S. Army), National Archives and Records Administration, Washington, DC. Hereafter, cases from these records will be cited as R.G. 153, NARA.

3. There were two trials over a period of four months in 1864. Trials of James Halon, 20 $0^{\text {th }}$ New York Cavalry, LL2552, John Brennan, William Cahill, Owen Curren, Thomas Hunt, Nicholas Kane, Edward Pickett, $20^{\text {th }}$ New York Cavalry, NN2468, R.G. 153, NARA.

4. Trial of J.C. Webb, NN2046, R.G. 153, NARA.

5. Jane Schultz, "The Inhospitable Hospital: Gender and Professionalism in Civil War Medicine," Signs 17.2 (1992): 363.

6. Trial of Andrew J. Smith, $11^{\text {th }}$ Pennsylvania Cavalry, NN2209, R.G. 153, NARA. 7. Susan Brownmiller noted in Against Our Will that, while some historians call the Civil War a "low rape war" (88), she stands "ready to be corrected by some later historians." Susan Brownmiller, Against Our Will: Men, Woman, and Rape (New York: Fawcett Columbine, 1975) 416. George Rable concedes that "rapes did occur" but points also to the paucity of research devoted to illuminate this 
subject. George Rable, Civil Wars: Women and the Crisis of Southern Nationalism (Chicago: U of Illinois P, 1989) 161, and fn. 25, 341. Victoria Bynum observes that "rape charges were unlikely to reach a courtroom," due to "deeply embedded notions of shame and honor" [that] "encouraged private vengeance rather than public justice." Victoria E. Bynum, Unruly Women: The Politics of Sexual Control in the Old South Chapel Hill: U of North Carolina P, 1992, 118. Drew Faust maintains that, "[w]hite females, particularly those of the elite, were rarely victims of rape by invading soldiers" except in the case of guerrillas and other marauders who "were far more likely to challenge the usages of 'civilized warfare.' Black women, she notes, "served as the unfortunate sexual spoils when Union soldiers asserted their traditional right of military conquest." Faust, Mothers of Invention: Women of the Slaveholding South in the American Civil War (Chapel Hill: U of North Carolina P, 1996) 200, and fn. 6, 296. These circumspect references have prompted Ervin L. Jordan, Jr., to call rape "the silent subject of the Civil War [. . .] alluded to in letters, memoirs, and reports in a cloud of euphemisms]....]" Ervin L. Jordan, Jr., "Mirrors Beyond Memories: Afro-Virginians and the Civil War," New Perspectives on the Civil War, ed. John Y. Simon and Michael E. Stevens (Madison, WI: Madison House, 1998), 158, and "Sleeping with the Enemy: Sex, Black Women, and the Civil War," Western Journal of Black Studies 18.2 (Summer 1994): 55-63. Thomas Lowery has published two books that contain detailed descriptions of sexual conduct by Civil War soldiers. Thomas P. Lowery, The Story the Soldiers Wouldn't Tell: Sex in the Civil War (Mechanicsburg, PA: Stackpole Press, 1994) and Sexual Misbehavior in the Civil War: A Compendium (n.p.: Exlibris Corporation, 2006). Martha Hodes' study of wartime and postwar sexual relations between the races is, perhaps, the most comprehensive study to date. Hodes, White Women, Black Men: Illicit Sex in the Nineteenth-Century South (New Haven: Yale University Press, 1997). The prevalence of sexual violence in the American Civil war are discussed in Michael Fellman, Inside War: The Guerrilla Conflict in Missouri during the American Civil War (New York: Oxford UP, 1989): 207; Bell I. Wiley, The Life of Billy Yank: The Common Soldier of the Union (1952; 1971) 205; Joseph Glatthaar, Forged in Battle: The Civil War Alliance of Black Soldiers and White Officers (Baton Rouge: LSU Press, 1990) 118-119; and Crystal N. Feimster, "Rape and Justice in the Civil War," New York Times Opinionator, April 2, 2013.

8. Callie Marie Rennison, "Rape and Sexual Assault: Reporting to Police and Medical Attention, 1992-2000," U.S., Office of Justice Programs, Bureau of Justice Statistics, $\quad$ http://www.bjs.gov/index.cfm?ty=pbdetail\&iid=1133, accessed December 15, 2014. This report is based on data from the National Crime Victimization Survey.

9. For a discussion of women's bodies as a wartime terrain: Cynthia Enloe, Maneuvers: The International Politics of Militarizing Women's Lives (Berkeley: University of California Press, 2000); Ann L. Barstow, ed., War's Dirty Secret: Rape, Prostitution, and Other Crimes against Women (Cleveland, OH: Pilgrim Press, 2000); Laura Sjoberg and Sandra Via, eds. Gender, War, and Militarism: Feminist Perspectives (Santa Barbara, CA: ABC-CLIO, 2010); Lisa Heinemann, ed. Sexual Violence in Conflict Zones: From the Ancient World to the Era of Human Rights (Pittsburgh: University of Pennsylvania Press, 2011).

10. Wendy S. Hesford, "Reading Rape Narratives: Material Rhetoric and the Trauma of Representation," College English 62 (November 1999): 192-203. 
11. "An Act for enrolling and calling out the national Forces, and for other purposes," March 3, 1863, Chapter 75, Sec. 30, 12 Statutes at Large 731 at 736.

12. Most of these defendants were charged with conduct unbecoming an officer and a gentleman or conduct prejudicial to good order and military disciplinetwo broad charges that were part of the Articles of War and which covered a wide variety of misconduct. A few, however, were charged with sex-specific offences.

13. William Blackstone, Commentaries on the Laws of England (Notes by George Sharswood) Book IV, Chapter XV, Sec. 210. 2 vols. (Philadelphia: George W. Childs, 1862), 2:474.

14. Trial of C. A. Goff, W. H. Knapp, H. F. Blakeslee, and W. H. O'Dell, $4^{\text {th }}$ Corps d'Afrique, NN1332, R. G. 153, NARA.

15. Trial of Alonzo Nightingale and Lawrence Dorgan, 24 ${ }^{\text {th }}$ Regiment Massachusetts Volunteers, NN1279, R.G. 153, NARA.

16. Trial of Eugene Hannel, $2^{\text {nd }}$ Maryland Regiment, MM987, R.G. 153, NARA.

17. Trial of Eugene Hannel, $2^{\text {nd }}$ Maryland Regiment, MM987, R.G. 153, NARA.

18. Holt to Secretary of War, December 28, 1863, Records of the Office of the Judge Advocate General (Army), Correspondence, Letters Sent, Entry 1, Vol. 4, p. 457 , R.G. 153 , NARA.

19. Trial of Thomas Bond, $9^{\text {th }}$ Pennsylvania Reserve Corps, NN3927, R.G. 153, NARA.

20. Trial of Robert Henry Hughes, Quartermaster's Department, MM1470, R.G. 153, NARA.

21. Sutler: a civilian provisioner to an army, often with a shop in the camp or on the post.

22. Trial of Samuel D. Fitch, $6^{\text {th }}$ U.S. Colored Cavalry, OO789, R.G. 153, NARA.

23. Trial of Jacob K. Schuck, $5^{\text {th }}$ U.S. Colored Cavalry, OO1185, NARA. Emphasis in the original.

24. ${ }^{24}$ Trial of Charles Lauer, $55^{\text {th }}$ Pennsylvania Volunteers, NN624, R.G. 153, NARA.

25. Trial of John C. Barger, $11^{\text {th }}$ Tennessee Cavalry, NN1699, R.G. 153, NARA.

26. Trial of Jerome Taft, 59 ${ }^{\text {th }}$ New York Infantry, II704, R.G.153, NARA.

27. Trial of Samuel N. Stanford, $1^{\text {st }}$ Ohio Cavalry, NN15409, R.G. 153, NARA.

28. Trial of Jacob K. Schuck, $5^{\text {th }}$ Regiment U.S. Colored Cavalry, OO1185, NARA.

29. Trial of Andrew Jackson Smith, $11^{\text {th }}$ Pennsylvania Cavalry, NN2099, R.G. 153, NARA.

30. Potiphar appears in the book of Genesis as the captain of the pharaoh's palace guard. His wife attempted to seduce Joseph, who had been sold to Potiphar as a slave by the Ishmaelites. When Joseph resisted her advances, she claimed he had tried to rape her. Nineteenth-century Americans would have been quite familiar with this reference. Bible, Genesis 39: 1-20.

31. Trial of Andrew Jackson Smith, NN2099, R.G.153, NARA.

32. The literature is extensive. For instance, Mary Louise Roberts, What Soldiers Do: Sex and the American GI in WWII in France (Chicago: U of Chicago $\mathrm{P}$, 2013); Alice Kaplan, The Interpreter (Chicago: U of Chicago P, 2007); J. Robert Lally, Taken by Force: Rape and American GIs in Europe During World War II (New York: Palgrave Macmillan, 2003); Raphaelle Branch and Fabrica Virgili, eds., Rape in Wartime (New York: Palgrave Macmillan, 2013); Ana Carden-Goyne, Gender and Conflict since 1914: Historical and Interdisciplinary 
Perspectives (New York: Palgrave, 2012); Julie Mertus, War's Offensive on Women: The Humanitarian Challenge in Bosnia, Kosovo, and Afghanistan (West Hartford, CT: Kumarian Press, 2000); Heli Askola, Rape in Armed Conflict: International Criminal Prohibitions and Their Enforcement (Turka: Publications of the Faculty of Law of the University of Turka, 2000).

33. Halon was charged with four offenses: Grace Barnes's rape, assaulting a guard, and striking and threatening to shoot two superior officers. He was found guilty of all but the assault on the guard and served a three-year sentence wearing a 24-pound ball and chain. Trial of James Halon, 20 ${ }^{\text {th }}$ New York Cavalry, LL2552, R.G. 153, NARA.

\section{ABSTRACTS}

The American Civil War drew thousands of white and black women into paid and unpaid work for the Union and Confederate armies. While the armies provided some women with a reliable income, their very proximity also represented a dangerous liaison that drew them into closer contact with Union troops that rendered them vulnerable to sexual assault. By 1865, more than four hundred Union soldiers had been court-martialed for sexual crimes against white and black women and girls. At the war's onset, the Union's judge advocate corps, which tried soldiers for violations of the articles of war, was ill-prepared to adjudicate sexual crimes. By the war's end, however, an ethic of sexual justice emerged from Union military courts to provide women with a means of redressing their wartime sexual violation.

\section{INDEX}

Mots-clés: Abraham Lincoln, Alecia P. Long, Alice Kaplan, Amanda McGee, Ann Cardon-Goyne, Ann L. Barstow, Bell I. Wiley, Benjamin Butler, Callie Marie Rennison, Charles F. Ritter, Crystal N. Feimster, Cynthia Enloe, Drew Gilpin Faust, E. Susan Barber, Edwin Stanton, Ervin L. Jordan, Fabrica Virgili, George Meade, George Rable, H. G. Meminger, Harriet Merrill, Heli Askola, J. Robert Lally, Jane Schultz, John Y. Simon, Joseph Glatthaar, Joseph Holt, Jr., Julie Mertus, Laura Sjoberg, LeeAnn Whites, Lisa Heinemann, Martha Hodes, Mary Louise Roberts, Michael E. Stevens, Michael Fellman, Raphaelle Branch, Sandra Via, Sarah Jane Sedman, Susan Brownmiller, Thomas P. Lowery, Victoria Bynum, Wendy S. Hesford, William Blackstone

Keywords: American Civil War, courts-martial, Rape, sexual assault, Union Army, women

\section{AUTHORS}

\section{E. SUSAN BARBER}

3504 Millvale Rd., Baltimore, MD 21244 ; sbarber@ndm.edu

\section{CHARLES F. RITTER}

3024 N. Calvert St., Apt. A-3, Baltimore, MD 21218; critter@ndm.edu 